\title{
COMPLEX PROBLEM ANALYSIS OF THE HUNGARIAN DAIRY FARMS
}

\author{
Beáta Blaskó, Krisztián Kovács, László Szőllősi, István Szűcs \\ University of Debrecen Centre for Agricultural and Applied Economic Sciences \\ Faculty of Applied Economics and Rural Development Institute of Business Economics \\ Hungary, H-4032 Debrecen, Böszörményi Str. 138. \\ blaskob@agr.unideb.hu,kovacskrisz@agr.unideb.hu,szollosi@agr.unideb.hu,szucsi@agr.unideb.hu
}

\begin{abstract}
Hungarian dairy farms went through significant changes in past two decades. The most significant changes were caused by our accession to the European Union in 2004. In Hungary milk production remarkably declined after EU accession due to the decreasing level of support and decreasing milk prices. Size of our dairy herd has been practically reducing since the political transformation (1989); meanwhile the relative yields per cow have been continuously increasing. Relatively low prices, high production costs and tightening quality requirements ousted several producers - mainly small farms - from the market in past years. Feeding cost represents the highest rate in cost structure of production, but animal health expenditures and various losses are also significant. Applied technology of the Hungarian dairies lags behind the Western-European competitors'; in addition they have handicaps in efficiency and product innovation. Moreover Hungarian milk and milk product consumption is about half of the Union average.

In 2007 at the University of Debrecen the opportunities and the problems of this sector were discussed in the framework of a research and development project entitled "Project-generating based on sector-specific innovation". At this workshop farmers, experts and advisers shared their ideas which were all gathered. The main objective of our paper is to provide useful information for the decision makers and the most important members of the sector. Using the practically successful ideas plus the ideas based on previous experience a new strategic concept was created.

To reach the objective of this paper we collected, synthesized and analysed the strengths, weaknesses, opportunities and threats of the dairy farms and performed a SWOT analysis. On the basis of this SWOT analysis we set up a well organised problem hierarchy which would help to identify the main weaknesses of the sector. This analysis gives a great framework for the researches and it also gives a useful tool for the decision makers to improve the competitiveness of the Hungarian dairy sector.
\end{abstract}

Keywords: Hungarian dairy farms, complex problem analysis, SWOT analysis, problem tree

\section{Introduction}

In the last twenty years animal breeding was remarkably regressed compared to the previous decades in Hungary. This decrease was serious mainly in the dairy sector, where the size of the national dairy herd declined from 630 thousand to 309 thousand animals (HCSO, 2011). It is obvious, that there are some serious problems in the Hungarian dairy sector. Some experts in different fields have their own ideas about these problems, but so far, nobody has made a complex problem analysis for the Hungarian dairy sector to help creating a single national strategy to develop this sector.

This research focuses on the competitiveness of the Hungarian dairy farms. The general objective of this paper is to answer the following questions: What are the strong and weak points of the Hungarian dairy farms? What kind of problems have nowadays the Hungarian dairy farms faced on? To reach our objective the first task is to give a brief outlook of the World, European and the Hungarian dairy sector. Our second task is to collect, synthesize and analyse the strengths, weaknesses, opportunities and threats of the dairy farms and performed a SWOT analysis. The third task of this paper is to create a problem tree of the farms on the basis of the SWOT analysis, which looks for the main problems and searches for the action-reaction contacts into logically arranged tree structure which also gives a useful tool for the decision makers to improve the competitiveness of the Hungarian dairy farms.

\subsection{International outlook - World dairy sector}

On the basis of assumption world milk production in 2010 reaches 711 million tonnes. Milk production is expected to increase and it can even rise above 794 million tonnes in 2017. Figure 1. shows the tendency of world milk production between 1996 and 2010. In 2010 there is an increase of $1.6 \%$ from last year, but it remains below the $2.1 \%$ average annual growth experienced in the past decade.

The major contributors of the production growth in 2010 are India and China, but Brazil, the EU(27) and the United States also play important role in it. 


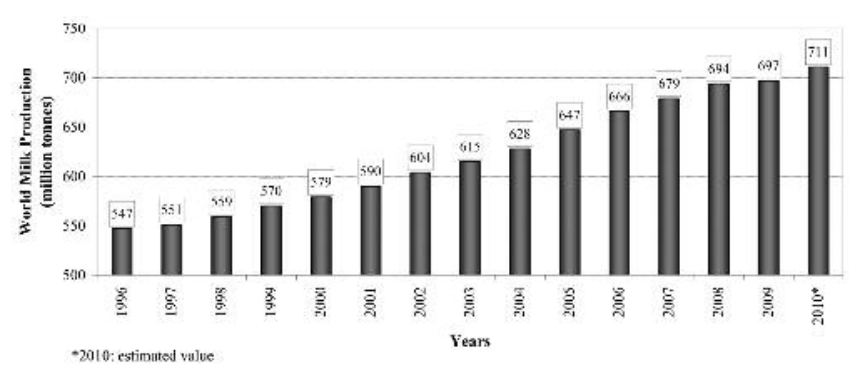

Figure 1: World milk production from 1996 to 2010 Source: FAO-OECD, 2011

Figure 2. illustrates the top 10 milk producers of the world and their contribution to world milk production. The $\mathrm{EU}(27)$ is the most significant milk producer in the world with its 153 million tonnes production, although its production rate remains at the same level in 2010.

The production of the Russian Federation is 33 million tonnes in 2010, and there is only a slight growth in it due to the increase of feed prices. In 2010 production increases by almost 3\% to 61 million tonnes in South America, where Brazil gives one-third of total milk production.

In Oceania farmers could expand output last year due to good weather conditions. New Zealand is expected to reach 18 million tonnes production, which demonstrates a $6 \%$ growth, while in Australia growth is only $2 \%$ due to high feed prices, so production is more than 9 million tonnes. In Africa milk production reaches 37 million tonnes in 2010, it demonstrates a slight $1.3 \%$ growth.

All over the world people cover approximately $13 \%$ of their protein requirement from milk and milk products based on the available data and estimates. There is a continuous growth in consumption of milk and milk products and this tendency will probably not change. In 2009 however, for the first time in years the global per capita consumption of milk declined by $0.4 \%$. The main reason for the decline was the complex credit crisis in the world economy. Another reason for the decrease was the slowing down in the growth of Chinese dairy consumption due to the melamine crisis. On the basis of FAO-OECD data per capita milk and milk product consumption was $103.0 \mathrm{~kg}$ in 2009 . As regards the consumption of developed countries the average level of it is $245.0 \mathrm{~kg} / \mathrm{capita} / \mathrm{year}$, while in developing countries it is only $66.2 \mathrm{~kg} / \mathrm{capita} /$ year. The consumption level of milk and milk products is expected to expand by $1 \%$ and reach the value of $104.3 \mathrm{~kg} / \mathrm{capita} /$ year (FAO-OECD 2010). The ideal and healthy level of milk and milk product consumption would be $260-270 \mathrm{~kg} / \mathrm{capita} / \mathrm{year}$. Developed countries approach this level, but in developing countries the level of milk consumption is far below the healthy value (Szakály 2006).

Consumption of milk and milk products significantly depends on income, so liquid milk can be considered an inferior good. An inferior good is a good that decreases in demand when consumer income rises. As the consumers become monetarily better off (earn higher incomes) the

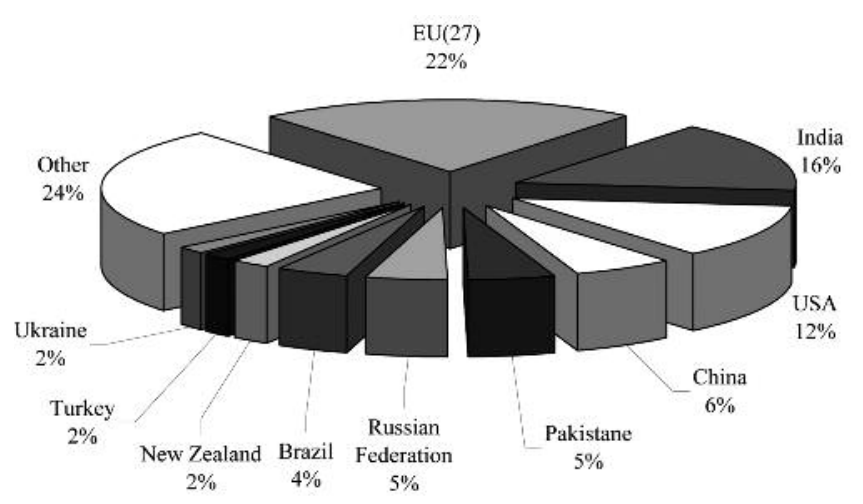

Figure 2: Distribution of world milk production (697 million tonnes) in 2009 Source: FAO-OECD, 2011

demand for such goods (such as liquid milk) falls because consumers can now afford higher priced substitutes. In accordance with the above-mentioned definition the consumption of liquid milk rises up to a certain point (income) and then its consumption slows and starts to decrease since processed products with higher added value (mainly butter, cheese and yoghurt) take its place.

The ratio of international trade of milk and milk products to production is $6 \%$, i.e. 42 million tonnes, and it may expand, driven by strong demand from Asian countries and the Russian Federation. Export growth results from the United States, New Zealand and the EU(27). There is a strong import growth in Asian countries and the Russian Federation. In addition, Algeria, Mexico, Saudi Arabia and the United States are also relevant importers.

Since the start of 2009 the dairy market was confronted with a period of extraordinary law prices. The financial and credit crisis in the world economy had a dramatic impact on product prices during the first half of the year 2009. After bottoming out, prices were slowly stabilising during the second part of 2009. At the end of the summer international prices started to strengthen. The strong recovery in prices was triggered by increases demand, mainly from oil exporting countries, but also from China. The last quarter of 2009 was characterized by steady rise in prices.

Analysis of the world market price of the most important dairy products it represents a strong recovery from last year, but it still remains 20\% below its peak value in early 2008 . However prices have doubled compared with prices of period of 2002-2004. Export prices in Oceania in September 2010 were USD/tonnes 4100 for butter, 3140 for SMP ${ }^{1}, 3360$ for $\mathrm{WMP}^{2}$ and 3950 for cheese.

In conclusion 2009 showed a mixed picture: a stagnating first half year and a strong recovery during the second part. Dairy sector looks much more balanced in 2010.

\subsection{Dairy situation in the European Union}

The European Union is the largest contributor to the world milk production. The EU(27) produced 153 million tonnes

${ }^{1}$ Skim Milk Powder
${ }^{2}$ Whole Milk Powder 
milk in 2009. Figure 3. demonstrates the distribution of milk production within the $\mathrm{EU}(27)$, where France, Germany, the United Kingdom, Italy, Poland and the Netherlands give the $67 \%$ of total milk production. Hungary with its $1 \%$ contribution to the $\mathrm{EU}(27)$ production is placed as 19.

The average liquid milk consumption in the EU(27) was 32.2 million tonnes and $64.5 \mathrm{~kg} / \mathrm{capita}$ in 2009 . These values show a $1.2 \%$ decrease in comparison with the year 2008. Within the $\mathrm{EU}(27)$ the top six consumers are Estonia, Ireland, Finland, the United Kingdom, Sweden and Denmark. As liquid milk consumption butter consumption also decreased in the EU(27) in 2009. Its average value was 1.7 million tonnes and 3.5 $\mathrm{kg} / \mathrm{capita}$. France, Germany, the Czech Republic, Austria, Poland and Estonia are on the top of butter consumption. Cheese consumption of the $\mathrm{EU}(27)$ was almost 8.3 million tonnes in 2009 and it increased by almost $1 \%$ in comparison with the previous year. The average per capita cheese consumption was $16.6 \mathrm{~kg}$. Greece, France, Germany, the Netherlands, Italy and Finland consumed cheese in the largest quantity.

The second major exporter of milk and milk products in Zealand. The level of import is much more lower, the $\mathrm{EU}(27)$ imports 1.2 million tonnes milk and milk products. Both in the export and import structure cheese represents the highest rate. the world is the EU(27) with 9.9 million tonnes after New-

raw milk production has been continuously falling down. Currently the national milk production is around 1.7 million tonnes (Figure 4.).

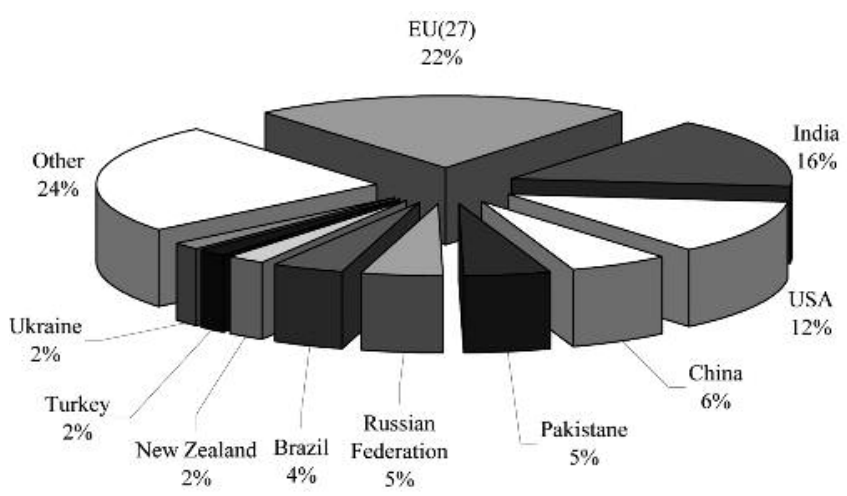

Figure 4: The evaluation of the Hungarian dairy sector Source: $\mathrm{HCSO}^{3}, 2011$

As Figure 4. illustrates the number of dairy cows significantly declined in the past twenty years. In accordance with the aforementioned statement the specific yield per cow was able to compensate this decline in cow number, so the volume of raw milk production remained stable. This correlation is down to the fact that with our EU accession most of the rural dairies ceased to exist and small producers with only a few dairy cows and low yields were forced to stop production. In this way the average Hungarian yield per cow started to increase.

Figure 5. demonstrates the level of milk and milk product consumption from 1987 to 2009 in Hungary. 1987 was an outstanding year in per capita consumption, because in this year Hungary managed to approach the consumption level of Western-European countries. Currently the average level of milk and milk product consumption is about $145-165 \mathrm{~kg} / \mathrm{capita} / \mathrm{year}$, which is only the half of the average of the most developed European countries. In all probability cheese consumption will Source: FAO-OECD, 2011

\subsection{Brief overview of the Hungarian dairy sector}

In the last two decades the number of the Hungarian dairy cows declined from 630 thousand to 311 thousand animals. In the beginning the decreasing number of cow livestock was not perceptible in the amount of raw cow milk production, which was around 1.9-2.1 million tonnes. Later the increasing specific cow yield was not able to compensate the national milk production descent. Since then the Hungarian increase in the next few years in Hungary.

The EU accession was defining in all aspects; it had significant impact on our foreign trade position (Figure 6.). After 2004 Hungary become a net importer in the field of milk and milk products. Currently we primarily export liquid milk to Italy, Romania and Slovenia. While milk products with higher added value arrive from Germany, Poland, Slovakia and the Czech Republic. Our foreign trade balance is unanimously negative. 


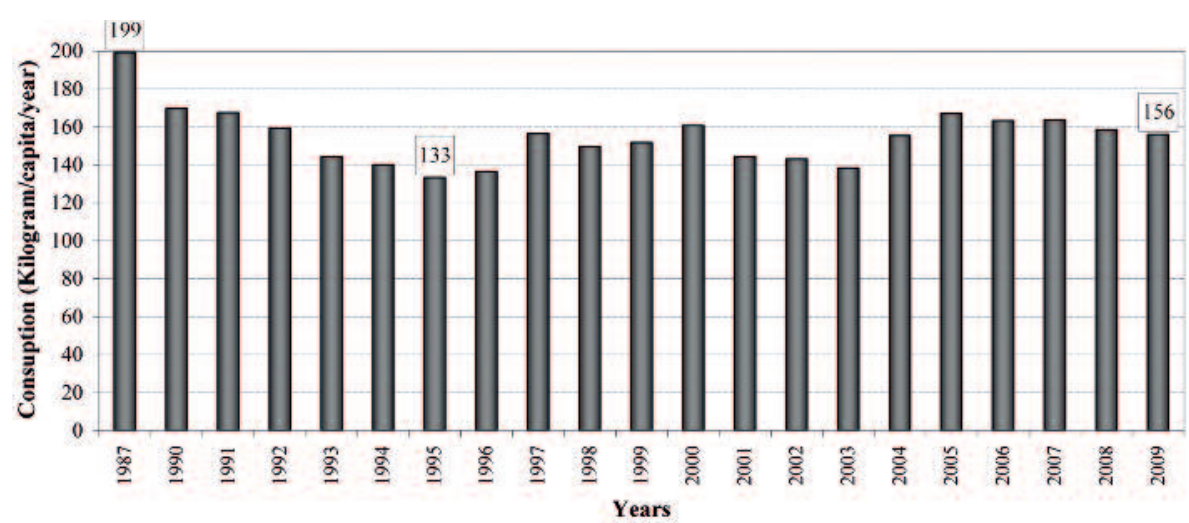

Figure 5: The evaluation of the Hungarian milk and milk product consumption Source: HCSO, 2011

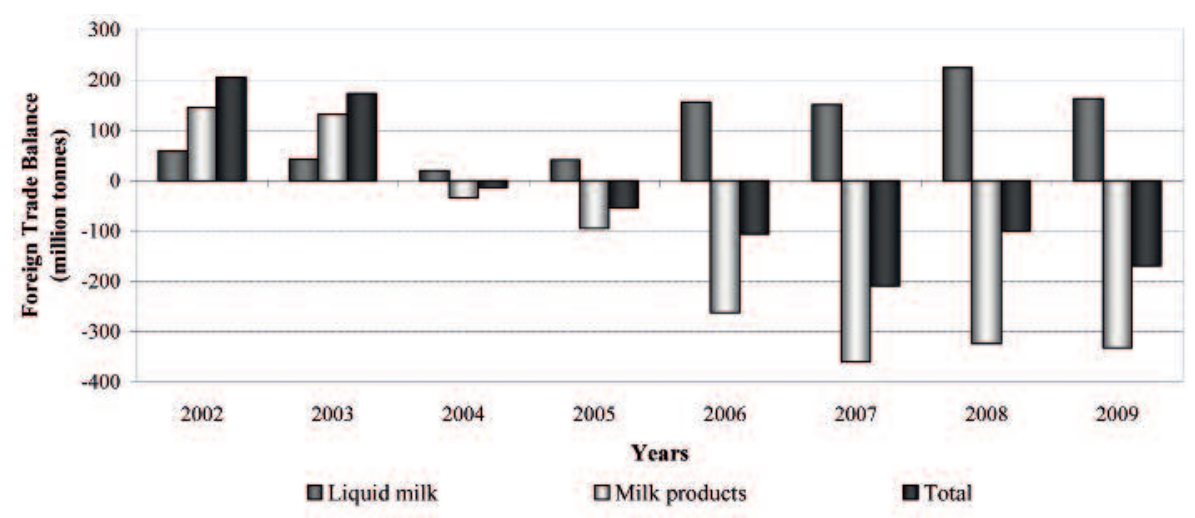

Figure 6: Foreign trade position of Hungary in the field of milk and milk products Source: HCSO, 2011

\section{Materials and Methods}

Present study carries out the SWOT analysis of the Hungarian dairy farms and on the basis of it we set up a well organised problem hierarchy which would help to identify the main weaknesses of the sector.

In 2007 at the University of Debrecen the opportunities and the problems of dairy sector were discussed in the framework of a research and development project entitled "Project-generating based on sector-specific innovation". Systematically we collected current weaknesses and problems of the dairy sector in our work, which is reflected the experts' opinions being participated in the abovementioned workshop and our views about the sector completed by secondary research.

In the first part of the research work we create a SWOT matrix and do the SWOT analysis, which is a "snapshot" with a tabular form and it demonstrates the current status of the examined sector. Results of the SWOT analysis are assorted according to four aspects, these are the followings: strengths, weaknesses, opportunities and threats (Szücs 2004).

The upper section contains, „Strengths” and the „Weaknesses” which summarize of the inside criteria appertaining to the examined sector, the lower section contains outside outlooks called, „Opportunities”, and the „Threats" which summarize the outside environmental facts.

By means of the SWOT analysis the following step of this study is to set up the problem tree of the dairy farms. The problem tree method is a hierarchic system looks for sectorial main problems and searches for the action-reaction contacts.

With the application of these methods we will be able to answer our research questions and give a comprehensive picture about the challenges of the Hungarian dairy farms.

\section{Results and Discussion}

This section presents the results of the Hungarian dairy farms' SWOT analysis which is followed by the problem tree.

\subsection{Presentation of the Hungarian dairy sector's SWOT analysis}

The sectorial experts' professional opinions and experience were completed by our secondary research, which contains bibliography review and statistical supporting. On the basis of these sources we set up together the sector's SWOT analysis, which also helps to create strategies (Figure 7.).

In the SWOT matrix we create four kinds of improvement strategies of the dairy sector. These strategies are: the offensive, changing oriented, defensive and diversificated strategies. The individual strategies engage the enterprise outer side elements (opportunities, threats) and interior elements (weaknesses, strength).

From the strengths high specific yield per cow and livestock concentration can be highlighted and attached to our proposed strategies, because these two factors can contribute to the increase of the sector's competitiveness. Production of milk products with higher added value (e.g. Omega-3 milk, as a functional food) would be important for the sector to create a competitive position in the export markets. From the opportunities expanding export market can contribute to reach this objective.

The weaknesses and threats were used to construct the problem tree of the dairy sector, which is introduced in detail in the next section. 


\begin{tabular}{|c|c|c|c|}
\hline & & $\begin{array}{ll} & \text { STRENGTH } \\
- & \text { High specific yield per cow index } \\
- & \text { Feeding based on cheap and good-quality corn } \\
& \text { silage } \\
- & \text { Livestock concentration } \\
- & \text { Good animal welfare condition } \\
- & \text { Several milk and milk products on the market } \\
- & \text { Professional feeding management }\end{array}$ & $\begin{aligned} & \text { WEAKNESSES } \\
- & \text { Higher and higher production costs every year } \\
- & \text { Low domestic milk consumption } \\
- & \text { Low level of integration in the production } \\
& \text { sector } \\
- & \text { Poor management level } \\
- & \text { Criss-crossed employment relations } \\
- & \text { Excellent experts become too old for work } \\
- & \text { Few information about the production } \\
- & \text { Low marketing activity } \\
- & \text { Low level of support }\end{aligned}$ \\
\hline & $\begin{array}{l}\text { OPPORTUNITIES } \\
\text { Favourable climatic conditions } \\
\text { Diverse technological knowledge } \\
\text { Expanding export markets } \\
\text { Good qualified veterinary surgeon } \\
\text { Increasing milk price (farm and consumer } \\
\text { price) } \\
\text { Good technical equipments (software) } \\
\text { Expanding opportunities for subsidies } \\
\text { Opportunities to make a good quality } \\
\text { feed } \\
\text { Excellent and motivated researchers }\end{array}$ & \begin{tabular}{|l} 
STRATEGY \\
- $\quad$ development of the feeding quality \\
- \\
$\begin{array}{l}\text { new export markets search for milk } \\
\text { products with high added value }\end{array}$ \\
- $\quad$ support more research activities about \\
competitiveness of dairy farms \\
improve the consumers' knowledge about \\
the healthy dairy products
\end{tabular} & \begin{tabular}{|l} 
STRATEGY \\
- $\quad$ effective exploitation of subsidies \\
- $\quad$ subsidies for the farm hygiene and to solve \\
the medical problems \\
- improve the collective marketing actions \\
- improvement of informatics infrastructure
\end{tabular} \\
\hline & $\begin{array}{l}\text { THREATS } \\
\text { Lack of consumers' loyalty and } \\
\text { unfavourable opinion about the animal } \\
\text { breeding } \\
\text { Increasing bio-ethanol utilisation } \\
\text { increases the feed prices } \\
\text { Demanding regulations (witch caused } \\
\text { high costs) } \\
\text { Low level research support } \\
\text { Good experts go abroad to work } \\
\text { Increasing feed prices }\end{array}$ & \begin{tabular}{|l} 
STRATEGY \\
- $\quad$ bring in the checked Hungarian product \\
brand \\
subsidy for the foreign and Hungarian \\
research, inspire the research projects \\
about the dairy sector \\
setting up of an innovative model farm for \\
the professional and public audience
\end{tabular} & $\begin{array}{l}\text { STRATEGY } \\
\text { - } \quad \text { use of energy saving opportunities } \\
\text { (renewable energy) } \\
\text { inspire the number of high level national } \\
\text { and international professional conference } \\
\text { - } \quad \text { improve the feeding technologies } \\
\text { search for new export markets for the raw } \\
\text { milk } \\
\text { inspire the collective power and the power } \\
\text { to enforce interests for the whole dairy } \\
\text { sector }\end{array}$ \\
\hline
\end{tabular}

Figure 7: SWOT matrix about the Hungarian dairy farms Source: Own construction

\subsection{The problem tree of the Hungarian dairy farms}

Hungarian milk production can be characterised by low income-generating capacity as the problem tree of the Hungarian dairy farms presents on the Figure 8. It essentially originates from four main problems: decreasing demand for domestic milk products, low farm prices, high production costs of dairy farmers and low level of other resources. Several factors play important role in development of this four defining problems.

The size of the Hungarian dairy herd decreased by $15 \%$ and milk production reduced by $14 \%$ in comparison with the data of the year preceding our accession to the European Union. On the basis of the HCSO (2010) database the size of our dairy herd is currently 309 thousand heads, while the amount of milk production is 1712 million liter. Due to the low level of cooperation in production stage of dairy product chain negotiation power of dairy farmers is poor and they can be described by increased defencelessness against the rest of the product chain. In recent years only one significant producer organization was established in production stage of milk product chain, the Alföldi Tej Értékesítő és Beszerző Ltd., which managed to gain decisive market share. This producer organization was established in 2003, and it received the final recognition in 2005 . The objective of this organization is the improvement of the profitability of milk production. On behalf of it the organization coordinates the following tasks: sale, production organization and consultancy, procurement, processing. The result of the increased defencelessness of dairy farmers is the weaker bargaining power against the dairies, which leads to low farm prices. However farm prices are depressed not only by the more concentrated processing sector, but the increasing presence of import products and the "unfavourable" product choice of price-sensitive consumers. Milk price became stable in 2007 and 2008 at a high level, internationally. Growing production and the economic crisis, however, led to a dramatic relapse in the price, leaving a number of producers in uncertainty (Borbély et al. 2010). On the basis of RIAE 4 (2011) database price of raw milk was $0.25 \mathrm{EUR} / \mathrm{kg}^{5}$ in January 2010, however it was already $0.30 \mathrm{EUR} / \mathrm{kg}$ in December. In reference to the datum of January 2011 price of raw milk was $0.31 \mathrm{EUR} / \mathrm{kg}$, which was approximately higher by $24 \%$ compared to data of previous year.

The above-mentioned consumer price-sensitivity and the growing demand for cheaper import products contribute to

\footnotetext{
${ }^{4}$ Research Institute of Agricultural Economics

5265,36 HUF/EUR (Hungarian National Bank, April 2011.)
} 


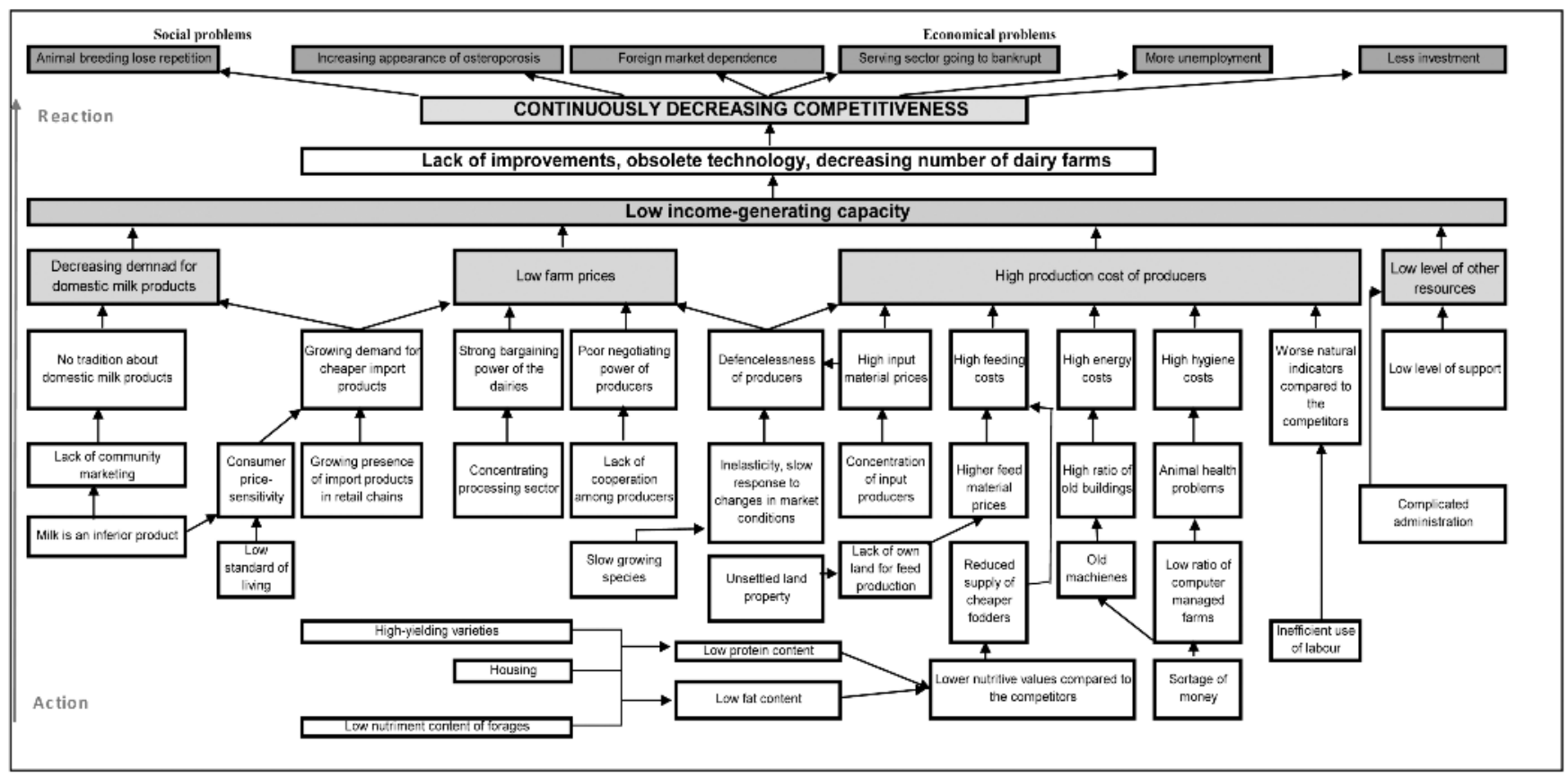

Figure 8: The problem tree of the Hungarian dairy farms

Source: Own construction

another main problem, to the decreasing demand for domestic milk and milk products. On the basis of HCSO (2010) data base the per capita consumption of milk and milk products is about $140-180 \mathrm{~kg} / \mathrm{capita} /$ year for ages in Hungary, and it was $178 \mathrm{~kg} / \mathrm{capita}$ in 2008 . This value is considerably lower than the EU average ( 260 $\mathrm{kg} / \mathrm{capita} / \mathrm{year}$ ) and the healthy level of consumption (260-270 kg/capita/year). Disposable income essentially determines the level of milk and milk product consumption of the Hungarian population. Hungarian consumers are not loyal for domestic products. In many cases they choose the cheaper import products of retail chains. They are usually not aware of the features and components of products, do not know the origin of them and they are not interested in the method of production, i.e. they are not conscious and in the first place price influences their buying decisions. Lack of community marketing is typical in Hungary. However the successfulness of this sector exactly depends on the creation of consumer awareness and strengthening of health consciousness, to which community marketing tools should be invoked (Popp et al. 2008). A survey carried out by Szakály et al (2005) also proved that in relation to milk and milk products significant misconceptions prevail among consumers. Essential interest of dairy industry is to clarify these existing misconceptions, since the lack of awareness building may have adverse effects on all categories of dairy products. Primary task is to strengthen consumer mentality among domestic products. Szakály et al. (2005) and Major (2007) also emphasise the importance of community marketing, which is beneficial to the participants, because they can preserve the independence of their core activity, but apportion the costs of advertising, market research, exhibitions and product policy among each other. However sectoral and national community marketing activity can not function effectively without the establishment of producer organizations and marketing cooperatives. The most important finding of Szakály et al. (2005) is that "the domestic community marketing can only be fully effective if a grassroots, marketing oriented system is managed to establish taking maximum into account the market needs and demands."

As described above the Hungarian consumer is specifically price-sensitive and less susceptible to the more expensive novelties. Nevertheless the domestic dairies are not able to compete with the cheaper, foreign mass products. Thus the market share of the domestic dairies continues to decline as a result of increasing import, which further reinforces the expansion of foreign dairy products (Popp et al 2010). Examining their values the import increased fivefold, while export doubled compared to the year prior our EU accession. Examining the product structure finished product sales are prevalent on the import side, while on the export side export of raw materials grew significantly. Our cheese export, which is primarily aimed at third countries, almost halved in the past. It must be highlighted that $80 \%$ of the import products come from the following four EU Member States: Germany, Poland, Slovakia, Czech Republic (Hungarian Dairy Association 2010).

Based on the experience of previous years it can be stated, that although the average milk yield of the Hungarian dairy herd - 6661 liter/cow/year based on HCSO (2010) is nearly $5 \%$ above the EU average, nevertheless not the volume of yields is the most important in terms of the profitability of milk production, but the cost of production. Hungarian milk production is relatively expensive in comparison with the competitors (Popp et al. 2008). Feeding costs represent the highest rate in cost structure of production, based on the statement of Vágó (2008) 43\% of 
the costs are feeding costs. One reason for the high feeding costs is that dairy farms often do not have their own land to produce feed. If they can do they produce the necessary feed in leased land, however in worse case they base their production on purchased feed placing them even more vulnerable position. Moreover there is decreasing supply of the relatively cheap sugar-beet processing and cannery byproducts, which further complicates the situation of producers. Losses from animal health problems can not be disregarded in the cost structure of production. In Hungary annual loss caused by reproductive disorders is roughly 150300 EUR/cow, which can even be $9-11 \%$ of the farm's revenue. Another significant problem also causing serious losses is mastitis (Ózsvári 2007).

However further problem beside high feeding costs is our worse natural indicators, which are often caused by poor feed conversion and in many cases inefficient use of labour. All the above-mentioned factors contribute to the high production costs of dairy farmers. In 2008 centre of average cost was 0.28 EUR in case of defining commodity producers. The so-called better farms could produce milk $27 \%$ cheaper, for 0.21 EUR, while the less cot-effective farms produced milk for 0.32 EUR. The differences mainly arise from the costs of feeding (Béládi and Kertész 2009).

Although the above-mentioned specific yield per cow is above the EU average, as regards the nutritive values Hungary falls behind the competitors. Compared with other Member States the average protein and fat content of domestic milk is relatively low, which in long run reduces the competitiveness of the dairies (Popp and Potori 2010). Based on (2011) the nutritive values of domestic raw milk are the followings: $3.29 \%$ protein, $3.72 \%$ fat. Poor nutritional indicators may be primarily caused by high-yielding varieties, inappropriate housing and low nutriment content of forages.

On the one hand low income-generating capacity results in the lack of technological improvements, so production can be characterised by increasingly obsolete technology; while on the other hand several producers are ousted from the market choosing sales from house or entirely giving up production. All these factors could further deepen our already existing competitive disadvantage against the Western-European competitors.

Common and defining problem of the dairies and the commercial sector is the inadequate level of milk and milk product consumption.

\section{Conclusion}

Applying the previously described methods we managed to define the typical strengths, weaknesses, opportunities and threats of the Hungarian dairy sector. The collected weaknesses and threats provided a good starting point to create the problem tree of the dairy farms.

Comparing all factors it can be concluded that the competitiveness of the Hungarian dairy farms is relatively low in comparison with the Western-European competitors. Currently the central problem of the dairy farms is the low income-generating capacity, which essentially originates from four defining problems: decreasing demand for domestic milk products, low farm prices, high production costs of producers and low level of other resources.

The aforementioned facts and main problems derive from several factors, some of which are:

- Hungary became a net importer in the field of milk and milk products.

- The consumption of the domestic milk and milk products decreased.

- Obtaining capital and credit is difficult due to the current credit crisis.

The present study provides useful information for the members and decision makers of the sector with the help of the defined strategies and identified problems.

\section{References}

Béládi, K., Kertész, R. (2009): A főbb mezőgazdasági ágazatok költség- és jövedelemhelyzete a tesztüzemek adatai alapján 2008ban. Agrárgazdasági Információk. 2009/4. 51-64.p.

Borbély, Cs., Geszti, Sz., Szentgróti, E., Leonhardt, B. (2010): A tejár változásának hatásai európai kitekintésben. Tejgazdaság. LXX. 2010/1-2. 47-51.p.

HCSO (2010): Statisztikai Tükör. Központi Statisztikai Hivatal, V. 3. $1-2$.

HCSO (2011): Mezőgazdasági statisztikai évkönyv 2010, Budapest, 40-45.p.

FAO-OECD (2011): database, http://faostat.fao.org/site/339/ default.aspx

FAO-OECD (2010): Food Outlook Global Market Analysis, November 2010. 49-52.p. http://www.fao.org/docrep/013/a1969e/ al969e00.pdf (downloaded: 10, January 2011)

Hungarian Dairy Association (2010): Agrárstratégia, A Tej Terméktanács javaslata a magyar tejvertikum vonatkozásában 2010-2020. http://www.tejtermek. hu/up/doc_news/ agrarstrategia_ 7fb339bf.pdf

Major, V. É. (2007): Tej- és tejtermékek jelentősége az egészséges táplálkozásban - trendek. Élelmiszer, Táplálkozás és Marketing. IV. 1/2007. 53-55.p.Mándi-Nagy, D. (2011): Agrárpiaci jelentések Tej és tejtermékek. Agrárpiaci jelentések. XIV. 2. 7.p.

Ózsvári, L. (2007): 'Drága a tehén, ha sánta!' Magyar Mezőgazdaság. 62. 29. 38-39.p.

Popp, J., Potori, N. (2010): Nemzetközi Agrárpiaci Kilátások. XIII. Magyarországi Mezőgazdasági Előrejelzési Konferencia. 60.p.

Popp, J., Potori, N., Papp, G. (2010): A magyar tejvertikum diagnózisa. Gazdálkodás. 54. 1. 81-91.p.

Popp, J., Potori, N., Udovecz, G. (2008): A versenyesélyek javításának lehetőségei az élelmiszergazdaságban. Agrárgazdasági tanulmányok. 2008. 107-114.p.

RIAE (2011): A nyerstej ára az EU-ban. https://www.aki.gov. hu/index.php

Szakály, Z.. (2006): Hazai és nemzetközi tendenciák a tej és 
tejtermékek fogyasztásában. In: Nábrádi, A., Béri, B. (Ed.) A tej ágazat aktuális kilátásai. Észak-Alföldi Regionális Szaktanácsadási Központ. Debrecen. 2006. 33-46.p.

Szakály, Z., Szente, V., Szigeti, O. (2005): A hazai közösségi marketingben jelentkező anomáliák és feladatok. Élelmiszer, Táplálkozás és Marketing, II. 1-2/2005. 7-10.p.
Szücs, I. (2004): Az üzleti tervezés folyamata. In: Szücs, I., Nagy, L. (Ed.) Gyakorlati Alkalmazások - Az üzleti tervezés gyakorlata. Campus Kiadó. Debrecen. 20.p.

Vágó, Sz. (2008): Az árakra ható tényezők, az árak szerepe, árelőrejelzés a magyar tejvertikumban. Doktori $(\mathrm{PhD})$ értekezés. Szent István Egyetem. Gödöllő. 83.p. 